\title{
Literary, Artistic and Architectural Exchange between Dutch and Polish Avant-Gardes: A Case Study in European Cultural Mobility in the 1920s and 30s
}

\section{Michał Wenderski}

To cite this article: Michał Wenderski (2016): Literary, Artistic and Architectural Exchange between Dutch and Polish Avant-Gardes: A Case Study in European Cultural Mobility in the 1920s and 30s, Dutch Crossing

To link to this article: http://dx.doi.org/10.1080/03096564.2016.1139785

\section{曲 Published online: 18 Mar 2016.}

Submit your article to this journal ๘

Q View related articles $\square$

View Crossmark data ¿ 


\title{
Literary, Artistic and Architectural Exchange between Dutch and Polish Avant-Gardes: A Case Study in European Cultural Mobility in the 1920 s and 305
}

\author{
Michat WENDERSKI \\ Faculty of English, Adam Mickiewicz University in Poznań, Poznań, \\ Poland
}

This paper reflects on cultural mobility in the interwar Europe exemplified by mutual exchange between Dutch and Polish avant-garde formations such as De Stijl or Blok. Polish and Dutch groups and magazines belonged to an international, cross-border network of avant-garde writers, artists and architects who jointly struggled for new, modern art. Within this network, magazines and artists from Poland and the Netherlands were related to each other regardless of apparent cultural and linguistic boundaries - not only via other formations (e.g. French or German), but also directly based on personal contacts between particular representatives of given groups. These relationships enabled direct, mutual and reciprocal exchange of texts and reproductions of artworks and architectural projects between Polish and Dutch magazines. Based on such tangible traces, as well as private correspondence between the artists, I describe the history and the maelstroms of cultural exchange between Dutch and Polish avant-gardes, which - being part of the transnational European avant-garde network - significantly contributed to the development of modern literary, artistic and architectural thought.

KEYWORDS: avant-garde, constructivism, cultural mobility, little magazines, Polish-Dutch exchange.

\section{Introduction}

The development of the twentieth-century art was much influenced by revolutionary currents and movements of the historical avant-garde, among others by International 
Constructivism. Developing simultaneously in various countries, it united writers, artists and architects from the whole continent who exchanged their artistic, architectural and literary theories boosting cultural mobility in the interwar Europe. Alongside representatives of French, German or Russian formations, also Dutch and Polish artists were key-actors in this transnational network - they launched new avant-garde magazines, joined international artistic groups and contributed to congenial formations. Despite apparent cultural or linguistic differences, the representatives of Polish and Dutch avantgarde circles were directly linked to each other, and traces of constant circulation of their works and ideas may be found in their magazines and correspondence. In the light of such explicit traces, I will reflect on mutual exchange between Polish and Dutch avant-garde periodicals as a case study of transnational cultural mobility in Europe of the 1920 and $30 \mathrm{~S}^{\mathrm{I}}$.

\section{Dutch constructivist magazines and formations}

The history of Dutch constructivism is inseparably related to De Stijl [The Style] a journal published between I9I7 and I932 by Theo van Doesburg. Although his artistic accomplishments are often questioned, especially next to other De Stijl artists such as Mondrian, Oud or Kok, ${ }^{2}$ van Doesburg played a very important role on the Dutch avant-garde scene. He was an active organizer, theoretician and inspirer and had a major impact on the Dutch-speaking avant-garde network. Van Doesburg personally ran the magazine and made it last so long, at the same time his difficult personality strongly marked those relationships, which often led to hostility and conflicts. Thus De Stijl was far from being a coherent or homogenous artistic collective. Throughout the years, the journal had a number of contributors (among others Cornelis van Eesteren, Gerrit Rietveld and Georges Vantongerloo), but the cooperation with most of them did not last long, mainly due to interpersonal animosities with van Doesburg. It was clearly reflected in a letter from I950 sent by Vantongerloo to Seuphor who claimed:

[...] n'oubli jamais que; V. d. Leck, Mondrian et Vantongerloo sont trois individus bien distinctes qui n'ont rien de commun avec le titre De Stijl ni avec De Stijl. Leurs traveaux sont trop individuels. V. Doesburg c'est servit de ces trois individus pour lancer et pour sa propagande personnelle. Cette vérité est telle que l'on a jamais considéré V. D. comme artiste mais bien comme propagandiste.

[...] don't ever forget that $\mathrm{V}[\mathrm{an}] \mathrm{d}[\mathrm{er}]$ Leck, Mondrian and Vantongerloo are three separate individuals who have nothing in common with the title De Stijl or with De Stijl. Their works are too individual. V[an] Doesburg used these three individuals to launch [De Stijl] and for his personal propaganda. The truth is that we have never considered $\mathrm{V}$ [an] $\mathrm{D}$ [oesburg] as an artist but as a propagandist. ${ }^{3}$

Besides De Stijl - which became the primary focus of the post-war avant-garde historiography and became a synonym of Dutch (contribution to) modern art ${ }^{4}$ - the Dutch constructivist scene was influenced and reflected by other periodicals, among others The Next Call, Het Woord, Internationale Revue iIo, and Mécano. The Next Call was 
published by Hendrik Nicolaas Werkman in Groningen between I923 and 1926. The Next Call had nine issues which were printed in an innovative technique based on Werkman's experiments with a traditional manually operated printing press. ${ }^{5}$ Even though the character, lifespan and scale of The Next Call differed a lot from De Stijl, they shared one key similarity, i.e. a devoted editor whose persistency and personal energy enabled its creation and functioning. Despite Werkman's attempts to engage other artists and to broaden the magazine's international reception, The Next Call did not include any foreign contributions. Werkman's correspondence and archival documents reveal his links to various European formations, including Polish Blok and Zwrotnica. ${ }^{6}$

Het Woord [The Word] was a short-lived magazine published in The Hague between August I925 and November I926 by Jan Demets in cooperation with Jan de Vries, Herwarth Walden, Ljubomir Micić and Eddy du Perron. It was an anti-traditionalist, internationally oriented magazine: it included contributions from several foreign artists besides Walden or Micić, also Huszár, van Ebeneth and Höch - as well as Werkman (his earlier unpublished work appeared in the fourth issue). Initially inspired by German Metz and van Doesburg's periodicals, Het Woord quickly gained a more defined constructivist character, comparable to Flemish De Driehoek. It was also the first Dutch magazine cooperating with du Perron, ${ }^{7}$ and it was in Het Woord where du Perron decided to kill off his literary alter ego Duco Perkens and write under his own name - Het Woord 2 included Perkens's fake obituary. ${ }^{8}$

Amsterdam-based revue $i_{\text {IO }}$ appeared between 1927 and I929, and was led by Arthur Müller-Lehning who established the journal in collaboration with Oud, Mondrian and Moholy-Nagy. iIo offered a wide range of various articles and works of some former contributors to De Stijl, such as Oud, Vantongerloo, Rietveld or Huszár, alongside Le Corbusier, Arp, Behne or Kandinsky. The international orientation of this journal was visible in the scope of texts which were published in Dutch, German and French. Notably none of van Doesburg's works or texts were published in $i_{I O}$, due to personal conflicts with other contributors to $i_{10.9}$ Van Doesburg did however contribute to other magazines, such as Het Getij (published in Amsterdam I9I6-24) or architectural periodicals De Bouwwereld (Amsterdam I902-24) and Het Bouwbedrijf (The Hague, I924-47). Under the pseudonym I. K. Bonset, he also published a Dadaist magazine Mécano (I92224) and later he planned - unsuccessfully - to launch a new journal Code with Michel Seuphor which according to den Boef and van Faassen was to become a counterpart to recent initiatives of Jozef Peeters, the editor of Flemish Het Overzicht and De Driehoek. ${ }^{\text {Io }}$

Instead, in I930 van Doesburg published the first and only issue of Art Concret and shortly before his death in March I93 I he got engaged in an international artistic group Abstraction-Création based in Paris. Its statutory declaration, with Herbin as president, van Doesburg as vice-president and Hélion as secretary, was issued on I 5 February I93I. ${ }^{\text {II }}$ The fact that the foundation of Abstraction-Création was partly ascribed to van Doesburg visibly outraged Vantongerloo, which he expressed for instance in his letter to Seuphor: 
Herbin a été désigné comme Président et moi comme Vice-Président [...] Après, bien longtemps après, on m'a dit qu'Hélion voulait faire une société avec V. D. ce qui n'a rien de commun avec Abs. Créa. Ce sont donc des interprétations mais ni le titre ni la société a été fondé par V. D.

Herbin was designated the President and me the Vice-President [...] Later, much later, I was told that Hélion wanted to form the association with V[an] D[oesburg], which has nothing to do with Abs[traction] Créa[tion]. These are thus just interpretations but neither the title, nor the association were founded by $\mathrm{V}[\mathrm{an}] \mathrm{D}[$ oesburg $] .^{\mathrm{I2}}$

Abstraction-Création somehow continued the activities of Cercle et Carré, a former international artistic formation founded in 1929 by Michel Seuphor and Joaquín TorresGarcía. Cercle et Carré featured works by numerous European artists, including Polish, and Dutch representatives, yet regardless of Seuphor's attempts to engage van Doesburg, he did not contribute to this initiative. In his invitation letter to van Doesburg Seuphor wrote: 'J'espère que vous ne refuserez pas de figurer aux côtés de Mondrian, Vantongerloo, Stazewski, Léger, Ozenfant, Torrès-Garcia, Léonce Rosenberg et bien d'autres.' [I hope that you will not refuse to figure side by side to Mondrian, Vantongerloo, Stażewski, Léger, Ozenfant, Torres-García, Léonce Rosenberg and others.]. ${ }^{\mathrm{I} 3}$ One after the other, Seuphor listed artists from Holland, Belgium, Poland, France or Uruguay who were joined in their pursuit of modern avant-garde art and shared common artistic values, no matter which background or nationality they represented. Yet, in his response van Doesburg argued that 'jamais un groupement sans base exclusive et strictement définiée, composé par des élements opposés, pourra marcher unanimenment "vers un ideal de construction"' [a group with no fixed basis or strict definition, consisting of opposing elements will never be able to advance unanimously towards 'the ideal of construction']. ${ }^{\mathrm{I}}$ Later, van Doesburg would harshly criticize this new initiative, as reflected in Torres-García's letter to Seuphor where we read: 'J'ai reçu une autre lettre de Doesburg où il critique et se moque de notre revue sans pitié.' [I have got another letter from [van] Doesburg where he criticizes and ridicules our magazine without mercy. $]^{\text {I5 }}$

\section{Polish constructivist magazines and formations}

Constructivist formations in Poland appeared in the first years of the I920s when Tadeusz Peiper founded Zwrotnica [The Switch]. Having spent the war and first post-war years abroad, in I92I Peiper returned to Poland as a great advocate of avant-garde art, yet his viewpoints - shaped by modern French and Spanish literary and artistic currents differed from poets debuting in Poland directly after the war. Hence Peiper's theoretic programme, based on different personal experiences and shaped in a different environment, found little recognition among his peers. ${ }^{16}$ Hence, in 1922 Peiper decided to launch a new literary and artistic movement in Poland by establishing Zwrotnica which soon became one of the most important nodes of Polish, if not European, avant-garde network. Zwrotnica was published in Cracow in two series (I922-23 \& I926-27), and its ideological program of Zwrotnica, although initially identified with futurism, ${ }^{17}$ corresponded to Ozenfant's and Le Corbusier's l'Esprit Nouveau fascinated with the functionality 
of the machine and constructivist architecture. ${ }^{18}$ Peiper himself was regarded as 'the father of Polish avant-garde' by his contemporaries who in vain tried to engage him in almost each artistic project which they were to establish after Zwrotnica - for instance while preparing a new journal Linia in I930 Przyboś claimed: 'Bez Peipera absolutnie nie możemy wystapić, a czekaliśmy 4 lata, możemy jeszcze 3 miesiące do jesieni.' [Without Peiper we may absolutely not begin, we have waited 4 years, we might as well wait 3 more months into the autumn.] ${ }^{\text {19 }}$

The major Polish constructivist group Blok was established 2 years later, yet the constructivist programme appeared already in 1923 in the catalogue of the Exhibition on New Art in Vilnius. The exhibition was opened on 20 May I923 and initiated by Witold Kajruksztis and Władysław Strzemiński who also prepared the exhibition catalogue. ${ }^{20}$ It contained numerous theoretical statements, which - even though they were all based on common constructivist ground - revealed the varied origins of the artists and their different standpoints. Four out of seven artists presented in the Vilnius exhibition, namely Strzemiński, Stażewski, Szczuka and Żarnower (joined by E. Miller), established Blok and published its first issue on 8 March I924. Yet, only the first four issues were published by the above-mentioned artists - as a result of tensions in Blok, Szczuka and Żarnower gained control over the journal and other artists left the group, mainly due to radical sociopolitical views of Szczuka. Blok featured articles and reproductions of its initiators as well as van Doesburg, Oud, van Eesteren and Werkman. The final issue of Blok was published in March I926 as a catalogue of the International Exhibition of Architecture in Warsaw.

Due to conflicts with Szczuka and Żarnower, artists such as Stażewski or Strzemiński together with professional architects previously cooperating with Blok became involved in another formation initiated by an architect Szymon Syrkus, namely Praesens. In June I926, the first issue of Praesens magazine appeared being generally shaped around Le Corbusier's Vers une architecture. In two issues of the journal (second one from May I930) theoretical papers were published, written both by the contributors as well as by foreign artists such as Piet Mondrian, Theo van Doesburg, J. J. P. Oud or Cornelis van Eesteren. In 1927 the group co-organized an exhibition of Malevich in Hotel Polonia in Warsaw - Malevich's first exhibition outside Russia, ${ }^{21}$ and several members of Praesens participated in the Machine Age Exposition in New York. The General National Exhibition $(P W K)$ held in 1929 in Poznań, a collective achievement of Praesens architects and painters, led to hostilities within the group and a split between these two fractions. ${ }^{22}$ As a consequence, Strzemiński and other painters left the group claiming that Syrkus and other architects destroyed their designs for PWK. Having published the second issue of Praesens, the group became exclusively devoted to architecture, and became much related to the CIAM organization.

Following the break-up of Praesens in I929, Strzemiński, Kobro and Stażewski established the $a$. $r$. group (revolutionary artists or real avant-garde) which was to unite all artistic disciplines: visual arts, architecture, typography and poetry. Strzemiński aimed to involve Peiper in his new initiative but the latter refused and instead - against Strzemiński's advice - cooperated with Praesens. ${ }^{23}$ Letters and articles written by Strzemiński between 
I928 and I934 reveal radical shift in his perception of Praesens - his initial esteem and appreciation for Praesens theories, which he linked to De Stijl's concept of art, turned into open combat against the magazine and its connections to Le Corbusier's ideas. ${ }^{24}$ a. r. did not create its own magazine but instead it issued short leaflet-like bulletins and published avant-garde books as part of the a.r.collection. A fragment of the first bulletin translated by Brzękowski into French was to be published in Cercle et Carré, yet Seuphor refused to do so because of its negative approach to Le Corbusier. ${ }^{25}$ The second $a . r$. bulletin was published with a major delay in December 1932, and although it gained a more opulent form, it did not have much recognition.

Moreover, between 1930 and 1936 the a.r. group issued eight books as part of a.r. library planning also to publish Polish translations of foreign texts, for instance Mondrian's Le Néo-Plasticisme, Marinetti's Let mots en liberté and other programmatic texts of European artists. ${ }^{26}$ Mondrian's letters to Michel Seuphor (8 December I926), J.J.P. Oud (20 December 1926), Félix del Marle (30 December 1926) and Albert van den Briel (n.d.)27 indicate that in 1926-27 Mondrian worked on the layout of the Polish version of Le NéoPlasticisme together with the artists related to Praesens and a.r. Nevertheless, the Polish version did not get published.

The fact that $a$. $r$. did not succeed to form a new organ of the Polish avant-garde, had to do with significant fragmentation and weak organizational structure of Polish art milieu. Following the closure of Zwrotnica in 1927, the Polish avant-garde scene had no firm base but a number of short-lasting and concurrent magazines such as Europa edited by Stanisław Baczyński or L'Art Contemporain - Sztuka Współczesna edited by Brzękowski and Chodasiewicz-Grabowska (Nadia Léger). L'Art Contemporain published Polish and foreign texts both in Polish and in French, aiming to become an important platform promoting Polish literary avant-garde abroad. Europa on the other hand was more socially and politically oriented. Internal animosities and lack of common ground within Polish artistic milieu of late I920s and early I930s bothered both Brzękowski and Strzemiński who deplored that their colleagues were not able to solidarize and cooperate. ${ }^{28}$ In the course of I930, they wanted to launch a new avant-garde journal which was to unite the Polish scene under one name and in May I93 I a journal named Linia was launched. ${ }^{29}$ Yet, it did not manage to constitute a new organ of the whole Polish avantgarde - programmatic differences, financial problems and interpersonal antagonisms proved to be insurmountable.

Nevertheless, despite internal divisions and antagonisms on Polish avant-garde scene, Strzemiński was able to establish an International Collection of Modern Art in I929-32, the first museum with permanent collection of modern art in Europe. Strzemiński had already envisaged establishing such a collection during his stay in Moscow where he witnessed growing interest in modern art in the course of the I920s. Between 1923 and I929, he repeatedly came forward with his project to other contributors to Blok and Praesens but before launching the $a$. $r$. group he did not gain enough attention and support. ${ }^{30}$ The collection eventually opened on I5 February I93I. The process of establishing and gathering the collection was mostly possible due to various international contacts between Polish and foreign artists. For instance Seuphor donated among others 
Werkman's Schoorstenen 2 from I923 - the very first artwork of Werkman to be exposed in a museum. Seuphor received it together with two other prints in August I925 while still editing Het Overzicht. ${ }^{\text {I }}$

\section{Cultural mobility between Poland and the Netherlands}

Constructivist formations from Poland and the Low Countries were parts of an international, cross-border network of avant-garde groups and magazines. Within this network, the aforementioned magazines and artists from Poland and the Netherlands were related to each other, not only via other formations (e.g. French or German), but also directly based on personal contacts between particular representatives of given groups. Such relationships enabled mutual, reciprocal exchange of texts and reproductions of artworks and architectural projects between magazines. The relations between Dutch and Polish avant-gardes date back to 1922 when Berlewi ordered the subscription of De Stijl. ${ }^{32}$ At that time Berlewi lived in Berlin, he participated in the Düsseldorf Congress of Progressive Artists, which allowed him to get acquainted with various representatives of European avant-gardes. ${ }^{33}$ Berlewi's contacts with van Doesburg and De Stijl artists were developed later by other representatives of Polish avant-garde formations. Van Doesburg received for instance the manuscript of Szczuka's I924 article 'Le mouvement artistique en Pologne', ${ }^{34}$ which did not however appear in De Stijl, but in Anthologie du Groupe Moderne d'Art de Liège. 35

The launching of Blok was reflected in De Stijl 6, 8 from 1924 which published a comment on its first two issues. The note acknowledged its resolute layout and claimed Blok's affinity to 'alle moderne richtingen van "Rousseau" tot "De Stijl" [all modern movements from 'Rousseau' to 'De Stijl']. ${ }^{36}$ It pointed also to Malevich's article in the second issue - the text in question was entitled 'O sztuce' [On art] and it was Malevich's first theoretical text to be published out of Russia. ${ }^{37}$ Moreover, the same issue listed Blok alongside other avant-garde magazines such as Mécano or The Next Call as one of journals, which 'verdienen bijzondere aandacht' [deserve particular attention]. ${ }^{8}$ Since the following issue (No. 6, 9 published in I925), Warsaw was listed as one of De Stijl's cities (with Leiden, Hannover, Paris, Brno and Vienna) on the cover of this magazine. While serving first and foremost for the magazine's propaganda, this fact was also a confirmation of the status of Warsaw as a fully fledged node of the avant-garde network.

Contacts between Dutch and Polish avant-gardes were further reflected in next issues of De Stijl. An 'Open brief aan den heer JHR. W. F. A. Roëll' (dated ro June I925 and published in De Stijl 6, Io/II) emphasized De Stijl's influence abroad, also in Poland. A list of books and magazines published in No. 7, 75/76 (I926) named among others Praesens, Zwrotnica and books by Jalu Kurek (Upaty), Julian Przyboś (Śruby) and Tadeusz Peiper (Szósta! Szósta!). ${ }^{39}$ What is more, in the jubilee issue Poland was included in a chart 'Invloedsverhouding van Stijlbeweging in het Buitenland sedert I9I7' presenting the influence of De Stijl abroad while Librairie des Beaux-Arts in Warsaw was listed as one of distribution points of De Stijl. $4^{\circ}$ According to van Doesburg's list of subscribers 'Abonnees boekhandel buitenland' from 1927, the library received four copies of 
De Stijl. Other subscription lists, such as 'Ruilabonnementen - Abonnements d'échange', 'Abonnees buitenland' (both I927) and 'Buitenland' (undated), include among others Zwrotnica, Biblioteka Politechniki Lwowskiej, Henryk Berlewi, Szymon Syrkus, Roman Sigalin and Jan Brzękowski.4 ${ }^{\mathrm{I}}$

Apart from De Stijl, few examples of Polish-Dutch exchange are to be found in other Dutch avant-garde journals. The Next Call bares only one explicit trace of its relationships with Polish formations, namely in the sixth issue from October I924 which listed The Next Call's congenial magazines, including Blok as well as De Stijl or Mécano.42 When it comes to $i_{I O}$, in 1927 Oud invited Syrkus to collaborate with the journal, ${ }^{43}$ and its fifth issue from 1927 published Syrkus's theoretical article 'L'architecture ouvrant le volume' accompanied by two reproductions of Malevich's and Stażewski's works. ${ }^{44}$ According to Syrkus's correspondence with Oud, however, more works of Polish provenance were to appear in $i_{10}$ - in September 1929 Syrkus sent 27 reproductions and architectural drawings as well as one issue of Dom $i$ Osiedle [House and Estate] asking Oud to choose relevant material to be published. ${ }^{45}$ Yet, none of this ever appeared in $i_{I O}$.

Polish elements present in De Stijl had a rather short, non-descriptive character. Nevertheless, in an architectural magazine Het Bouwbedrijf [The Building Industry] Polish architectural innovations received more attention. In a series of articles on new artistic and architectural solutions in Europe, van Doesburg discussed among others Poland. In two articles published in August 1930 and February I93I,${ }^{46}$ he described chosen theoretic aspects of Polish architecture coined by Malevich, Strzemiński, Szczuka and their practical implementation exemplified by the works of Stowarzyszenie Architektów Polskich [SAP, Society of Polish Architects] and Praesens architects such as Malinowski, Brukalscy, Szanajca, Lachert etc. To a far extent, however, van Doesburg's approach was rather stereotypical and superficial as he saw Dutch (=De Stijl's) contributions as more innovative and superior to Polish examples. Nevertheless, in his quite enthusiastic review of the second issue of Praesens, van Doesburg claimed among others that it reflected modern orientation and an excellent constructive perception while Syrkus's definitions of new construction methods were more interesting than those by Moholy-Nagy.47

In order to gather information for these articles, van Doesburg repeatedly wrote to Polish avant-garde artists and architects asking them for information and reproductions of their works. Stażewski's response to van Doesburg's request indicate that the latter had sent him a letter on Io October I928 asking for information and photos of current Polish works, and requesting to pass his letter to other artists. Stażewski delivered the request to Nicz-Borowiakowa, Strzemiński and Skulme and in reaction Polish artists sent van Doesburg a number of reproductions of their artworks. ${ }^{8}$ Later, van Doesburg sent similar requests to Andrzej Pronaszko, Witold Minkiewicz (believing that he was the editor of Architektura i Budownictwo) and to Roman Sigalin, one of SAP members who passed it to Jan Stefanowicz, the head of SAP. In his response, Stefanowicz sent van Doesburg 28 photos as well as two issues of SAP yearbook. ${ }^{49}$ Van Doesburg received a number of journals and reproductions of works by Brukalscy, Kobro, Malevich, NiczBorowiakowa, Rutkowski, Syrkus, Stażewski, Strzemiński, Szanajca and others, ${ }^{\circ}$ which he had used for the writing of his articles for Het Bouwbedrijf. 
Dutch architectural periodical de 8 en Opbouw [the 8 and Construction] also included a number of contributions of Polish provenance, for instance Syrkus's article 'Het nieuwe bouwen in Polen. De buitenmuur' [Modern building in Poland. The exterior wall] presented earlier during the fourth CIAM congress in Athens. The text was accompanied by twelve illustrations presenting architectural projects by Syrkus, Hempel and other Praesens architects. ${ }^{5}$ Moreover, Polish projects were used to illustrate other articles, for instance Syrkus's and Hempel's residential building in Katowice accompanied Boeken's text on functional architecture. ${ }^{52}$ Szanajca's and Brukalscy's Warsaw project appeared with Sijmons's article on gallery-access flats abroad ${ }^{53}$ and works by Praesens architects exemplified new solutions for exterior walls discussed in de 8 en Opbouw IO, I7/г8.54 The magazine also acknowledged Polish contributions to the works of CIAM or to the Parisian exposition in 1937 - for instance in Mart Stam's ${ }^{55}$ or Rietveld's articles. In his review of the Polish pavilion Rietveld wrote: 'In Polen zag ik een erg mooi interieur van Barbara Brukalska, [...] eigenlijk zeer geraffineerd, maar toch zoo natuurlijk.' [In Poland I saw a very nice interior by Barbara Brukalska, [...] actually very sophisticated, yet so natural.]. ${ }^{56}$ Further on, he described it more extensively and with much appreciation he valued for instance the fact that the exposition was not put in one big building but instead spread in smaller parts surrounded with trees, which reminded him of a park. ${ }^{57}$ Moreover, De 8 en Opbouw 6, 20 published a short note on Polish architectural periodical Architektura i Budownictwo..$^{8}$

Contacts with Dutch avant-garde artists were well reflected in Polish constructivist magazines, which reprinted their articles and reproduced their works. For instance Zwrotnica 8 illustrated Przybośs article 'Człowiek w rzeczach' [Man in things] with a number of 'Things which define the new man'59 among others van Doesburg's and van Eesteren's architectural model and Huszár's chessboard reproduced earlier in De Stijl 5, I2 from I922. L'Art Contemporain reproduced one work by van Doesburg and three by Mondrian including a previously unpublished composition 'Tableau-poème/Textuel' (co-created with Seuphor) which appeared in the first issue from April I929. After the war this artwork gained much renown, which was reflected in a postcard from National Museum of Modern Art in Paris sent by Seuphor to Brzękowski in May 1973. Seuphor wrote: 'Mon cher ami, Petite image en souvenir de "l'Art Contemporain" où tu fus le premier à reproduire le tableau, maintenant si connu.' [Dear friend, A small image in memory of 'L'Art Contemporain' where you were the first one to have published the tableau, now so well-known.]. ${ }^{60}$ At the same moment - in March I929-Mondrian's and Seuphor's work was published in Prague-based ReD (no. 2, 7) where it was compared to Teige's and Nezval's poems and 'deformed illustrations' from I923/25. 'Tableau-poème/ Textuel' appeared as well in Praesens 2 and in Cercle et Carré 2. Yet, interestingly enough, Cercle et Carré published only Seuphor's text, and Mondrian's layout of this artwork was omitted. Hence, this remarkable piece of avant-garde work originating from the Low Countries did not appear in its integrity in any of the analysed Dutch interwar avantgarde magazines, in contrary to two Polish (and one Czechoslovak) journals.

Having established Europa, Strzemiński asked key European artists to answer his short survey on modern art, and consequently Europa published Mondrian's and van 
Doesburg's reactions to the survey as well as the Polish translation of van Doesburg's manifesto of Concrete Art 'Base de la peinture concrète'. ${ }^{61}$ Moreover, in I928 Almanach. Katalog. Salon Modernistów published fragments of van Doesburg's Classique-BaroqueModerne. According to Brzekowski's letter to Przyboś, also the fourth issue of Linia was to publish some notes on De Stijl and Abstraction-Création, which however did not appear. ${ }^{62}$

It is though in Blok and in Praesens where one finds the most traces of Dutch-Polish exchange. Blok regularly referred to De Stijl and Mécano and it published reproductions of artworks by Theo van Doesburg (No. 2 and 5), Cornelis van Eesteren (No. 5), ${ }^{63} \mathrm{~J}$. J. P. Oud, Nieuwenhuis, Moholy-Nagy and Werkman (No. 8/9) as well as a translation of van Doesburg's article 'Odnowienie architektury' [The renewal of architecture] based on his text 'Tot een beeldende architectuur' from I924. ${ }^{64}$ Excerpts from this article were also incorporated in Blok's programmatic manifesto 'Co to jest konstruktywizm' [What is constructivism]. ${ }^{65}$ Contacts between Polish and Dutch architects were especially vivid, which resulted in numerous Dutch architects participating in the 1926 architectural exhibition in Warsaw. Having met van Doesburg and De Stijl architects during his stay in Berlin between 1922 and $1924,{ }^{66}$ Syrkus wrote to Oud in March I 925 asking for an article. Later their relation gradually developed into friendship mainly due to their engagement in the works of the CIAM organization where both Oud and Syrkus were very active. Hence, Syrkus invited Oud to participate in the 1926 exhibition $^{67}$ while Polski Klub Artystyczny wrote to van Doesburg. ${ }^{68}$

The exhibition catalogue (Blok II) listed I7 architectural projects by Oud, van Ravesteyn, Rietveld and van der Vlugt, and several furniture/interior designs by van Ravesteyn and Rietveld. Some of these works were also reproduced in Blok I I, including Oud's plans of Hoek van Holland, Rietveld's Schröder House and two of his famous chairs as well as van der Vlugt's School voor Nijverheidsonderwijs in Groningen (total of I6 illustrations). What is more, planning to incorporate short articles on modern French, German and Dutch architecture in the exhibition catalogue, in January I926 Polish artist Szczęsny Rutkowski wrote to van Ravesteyn and Oud asking for information on architectural innovations in the Netherlands. ${ }^{69}$ Whether Oud supplied Rutkowski with his text is unknown, eventually Blok I I published a short descriptive article 'Nowoczesna architektura holenderska' [Modern Dutch architecture] written by P. Meller and dated January 1926. Meller discussed the accomplishments of the abovementioned Dutch architects, particularly enthusiastically referring to Berlage and Oud. $7^{\circ}$

Having left Blok and established Praesens, Polish artists quickly informed their Dutch colleagues about their new initiative. In January I926 Stażewski, Syrkus and Rafałowski wrote to van Doesburg asking him to send some material for the first issue of Praesens in order to 'contribuer ainsi à la popularisation en Pologne des idées justes sur architecture' [contribute to the popularization of correct ideas on architecture in Poland]. ${ }^{\text {I }}$ In response, van Doesburg sent an article as well as his and Rietveld's works. Not being able to attend the Warsaw exhibition in I926, van Doesburg offered to visit Warsaw with a series of lectures, which unfortunately did not come to fruition although both parties were very keen on the idea. ${ }^{72}$ Syrkus wrote as well to Oud and informed him about the 
newly established Praesens and their plans for the first issue. Syrkus planned to reprint Oud's article from Soziale Bawwirtschaft and illustrate it with photos and plans of Oud's project for Oud-Mathenesse. Moreover, he mentioned that Praesens had already received contributions from van Doesburg and Rietveld, as well as from other artists. ${ }^{73}$ Oud's reaction to Syrkus's letter regarding the dissemination of van Doesburg's works is particularly interesting - in the manuscript from I2 April I926 we read:

Pour ce qui concerne la collaboration de M. van Doesburg, permettez-moi de vous avertir que c'est bien nécessaire de contrôler bien ce qu'on publie de lui. M. van Doesburg est un peintre avec beaucoup d'esprit, qui a écrit d'articles excellents sur la peinture moderne, mais qui - voyant finir la peinture en sa forme présente s'est sauvé dans l'architecture sans aussi le moindre idée de bâtir. N'ayant jamais bâti il proclame une architecture spéculative qui fait beaucoup de mal à l'œuvre des architectes modernes sérieux [...] pour ça c'est absolument nécessaire de savoir précisément ce qu'on publiera de lui et ce qu'on ne publiera pas.

With regard to the cooperation with M. van Doesburg, let me warn you that it is indeed necessary to strictly control which works of his get published. M. van Doesburg is a painter with much spirit, who has written excellent articles on modern painting, but who - seeing the painting end in its present form, has fled to architecture without the slightest idea how to build. Having never built he proclaims a speculative architecture which badly hurts the works of serious architects $[. .$.$] therefore it is absolutely necessary to know precisely which$ works of his will be published and what will not be published. ${ }^{74}$

Eventually, Praesens I published works by both Oud and van Doesburg. As envisaged by Syrkus, Oud's 'Wychowanie przez Architekturę' [Education through architecture; based on 'Erziehung zur Architektur' from Sociale Bawwirtschaft 5, 4] appeared, together with plans and two photos of Oud-Mathenesse (I922). Theo van Doesburg's article 'Ku Sztuce Elementów' [Towards Art of Elements] was accompanied by his three works from I924/25, the 1923 model of the artist's house by van Doesburg and van Eesteren, as well as one photo of Rietveld's house in Utrecht. Moreover, in the article 'Preliminarz architektury' [Preliminaries of architecture; Praesens I included also its French summary entitled 'L'Homme c'est animal qui a crée (sic) la mathématique'] Syrkus referred to works and theories by Mondrian, Oud and van Doesburg. A Polish translation of Oud's book Die Holländische Architektur, originally published in 1926 by Bauhaus, was also announced, of which Syrkus informed Oud in his letter from I6 June 1926 asking for reproductions necessary to publish the book. In the same letter, Syrkus expressed his interest in Oud's opinion of van Doesburg's role in architecture and asked him not to judge his viewpoints on architecture based on the contents of Praesens $\mathrm{I}^{75}$ - apparently Syrkus was not entirely satisfied with the first issue, most probably due to differences with Stażewski and Strzemiński.

Due to growing friendship between Syrkus and Oud, the latter's accomplishments were considerably better represented in Praesens than in Blok. Nevertheless, despite Oud's disapproval to van Doesburg's theories reflected in his correspondence with Syrkus, the latter did publish van Doesburg's works in Praesens I. Initially, the journal maintained good relations with van Doesburg and their correspondence indicates that beside the aforementioned series of lectures which van Doesburg was to give in Warsaw, the 
magazine also planned to organize a De Stijl exhibition in Warsaw and to publish a series of books with theoretical writings of Malevich, Mondrian, van Doesburg, Oud and Vantongerloo. ${ }^{76}$ Having published the first issue of Praesens, Syrkus and Stażewski sent a copy to van Doesburg and asked him for contributions to the second issue which was meant to appear in September 1926. They directly asked for photos of recent works of van Doesburg, Rietveld and Vantongerloo and emphasized that they would like to publish articles by van Doesburg and Vantongerloo. In his response van Doesburg wrote: 'J'ai bien reçu le numero I de votre belle revue et je vous remercie pour la belle page laquelle vous avez consacrée à moi. Si joint vous trouvez un petit article pour le prochain numéro, avec des photos.' [I have indeed received the Ist issue of your beautiful journal and I am grateful for the beautiful page which you have devoted to me. Enclosed you will find a short article for the following issue, with photos.]. ${ }^{77}$

Although Syrkus assured him that the received material would be published in Praesens 2, ${ }^{78}$ none of van Doesburg's works (and only one reproduction of Vantongerloo's sculpture) appeared in this issue. It coincided with Oud's and Syrkus's growing disapproval for van Doesburg's theories between I926 and I930, which was expressed in a letter from Szymon and Helena Syrkus to Oud: 'Un de ces jours nous étions dans la bibliothèque et nous avons feuilleté DE STIJL. C'est devenu terriblement présomptueux et faux. Mais tout d'un coup nous y avons trouvé votre photo. C'était une belle surprise - rencontre inattendue.' [One of these days we were in the library and we thumbed DE STIJL. It has become awfully presumptuous and false. But suddenly we found your photo. It was a lovely surprise - an unexpected encounter.].79

The second issue of Praesens was eventually published in May I930, 4 years after the first one. In his letters to Oud, Syrkus mentioned financial and organizational problems which gradually delayed the publication of this issue - originally expected in September I926, it got initially postponed by a year only to be finalized in May I930, partly due to Praesens's involvement in the $P W K$ exhibition. ${ }^{80}$ Deploring the lack of money and support for the avant-garde in Poland, Syrkus anyhow intended to publish a good-quality journal, bereft of the mistakes made in the previous issue. Hence, he asked Oud for a previously unpublished text (e.g. comparable to 'Ja und Nein' from Wasmuths Mantshefte) and when he realized that the received photos of Hoek van Holland had already been published many times, he requested new pictures and plans of Oud's Kiefhoek estate. ${ }^{8 \mathrm{r}}$

Finally, three articles of Dutch provenance were published in Praesens 2: Oud's 'Myśli' [Thoughts], van Eesteren's 'Funkcja-Przestrzeń-Forma' [Function-Space-Form] and Mondrian's 'Neo-plastycyzm' [Neo-plasticism] as well as Moholy-Nagy's 'Jeszcze o elementach' [More on elements]. Oud discussed the use of modern building materials such as glass or ferroconcrete illustrating it with his projects in Kiefhoek ( 5 figures), Hoek van Holland (3 figures) and others. Van Esteren's text described his I924 project of a commercial center by Laan van Meerdervoort in the Hague under the motto of simultaneité (presented also in De Stijl 6, I2). The article by Mondrian - illustrated by his works, a photo of Mondrian, Seuphor and Prampolini, and a sculpture of Vantongerloo - is a presentation of his neo-plasticist theories developed in La Vie des Lettres et des Arts and Le Néo-plasticisme. Praesens 2 reprinted also Mondrian's and Seuphor's 
'Tableau-poème/Textuel' originally published in April 1929 in L'Art Contemporain Sztuka Współczesna I.

Cultural mobility between Poland and the Netherlands was also reflected in Szymon Syrkus's article 'Tempo architektury' [The pace of architecture, Praesens 2 included also its French version entitled 'Le dynamisme de l'architecture moderne'] where he not only quoted Oud's thoughts on beauty from his book Die Holländische Architektur, but also referred to Oud's, Mondrian's and Moholy-Nagy's articles. Syrkus also discussed architectural and technical solutions of other Dutch architects such as de Klerk, van der Vlugt, Duiker and Byvoet illustrating it with photos of their works. The list of books received between I927 and I930 included four Dutch positions: Mondrian's Le Néo-plasticisme from I920 (I92I) and Neue Gestaltung. Neoplastizismus from I925, van Doesburg's Grundbegriffe der neuen gestaltenden Kunst (1925) and Oud's Holländische Architektur (I926) as well as Moholy-Nagy's Malerei, Fotografie, Film (I925) and Von Material zu Architektur (I929). ${ }^{82}$ Moreover, Praesens 2 published a short and very enthusiastic review of Lehning's magazine $i_{I}$ o pointing to Oud as head of architecture. ${ }^{83}$

Between 1922 and 1935, Polish architectural periodicals such as Architektura $i$ Budownictwo [AiB, Architecture and Construction] and Architekt [Architect] published a number of articles and illustrations related to Dutch modern architecture. AiB included articles written by van Doesburg ${ }^{84}$ and $\mathrm{Oud}^{85}$ as well as Polish texts describing new architectural solutions in the Netherlands, for instance a series of five articles by Lubinski 'Współczesna architektura holenderska' [Modern Dutch architecture] with numerous photos of works by among others Oud, van der Vlugt, Wils, Berlage, Byvoet, Kramer ${ }^{86}$ and other texts on low-cost housing, prefabricated construction or the late Berlage. ${ }^{87}$ Moreover, Dutch solutions and examples were mentioned or presented in a dozen other texts published in $A i B$ in this period. Like other journals, $A i B$ also listed various local and international magazines pointing to noteworthy solutions and projects. In I925-35, $A i B$ gave 27 examples of Dutch buildings, technical objects and architects referring to titles such as de 8 en Opbouw, L'Architecture d'Aujourd'hui and Moderne Bauformen.

Some other examples are to be found in Architekt - for instance the cover of its first issue from 1926 featured van Doesburg's, van Eesteren's and Rietveld's model of Hôtel Particulier. The article 'Nowe prądy w architekturze' [New architectural currents] published in the same issue and accompanied by projects by Oud (Café de Unie in Rotterdam), Rietveld (the famous Schröder House), van 't Hoff (Huis ter Heide), van Doesburg and van Eesteren (Hôtel Particulier), gave a broad description of Dutch modern architecture. Similarly, also thy summary of the Warsaw exhibition from March 1926 published in Architekt 2I, 5 featured many Dutch works (by van der Vlugt, Rietveld and Oud - all reproduced earlier in Blok II) and discussed these solution in the context of other works. ${ }^{88}$ Furthermore, the fifth issue from 1925 included an enthusiastic note on the Dutch pavilion for the Exhibition of Decorative Arts in Paris ${ }^{89}$ while Architekt 22, 5 announced the Internationale Tentoonstelling van Gemeentelijke Openbare Werken [International Exhibition of Municipal Public Works] in March I930 in Utrecht. ${ }^{\circ}$

Polish avant-garde artists maintained close ties with international formations such as Cercle et Carré or Abstraction-Création where Dutch artists were also key members. 
Each issue of Abstraction-Création. Art non-figuratif (between 1932 and 1936 five issues appeared) presented diverse contributions by a plethora of European artists including the representatives of Dutch and Polish avant-gardes. Abstraction-Création included for instance Mondrian's 'La néo-plastique'; van Doesburg's 'Élémentarisme’; Vantontgerloo's 'Préliminaire axiome', 'Evolution', 'Réflexion'; Stażewski’s ‘L’art plastique comme résumé de la vie culturelle’ and four other texts by Kobro, Strzemiński and Stażewski. The magazine featured also a number of artworks by van Doesburg, van der Leck, Mondrian, Kobro (four sculptures), Stażewski (four paintings) and Strzemiński (seven paintings). Moreover, an exposition of the Abstraction-Création group (c. 35 members) was planned to take place in Warsaw and in Lódź in February/March 1936 with the fifth issue of Abstraction-Création to become the exhibition catalogue. Initially, both parties (Vantongerloo as representative of the group, and Polish Institute for Art Propaganda) were very keen on the idea, yet the project failed due to financial obstacles. ${ }^{91}$

\section{Conclusions}

The aim of this paper was to present an inventory of explicit traces of cultural mobility between Polish and Dutch formations of the historical avant-garde and to discuss them in view of relevant archival material, for instance private correspondence between the artists. As a case study in cultural mobility in the interwar Europe, the above-mentioned examples visibly indicate that it had a mutual, reciprocal character and that the exchange between various formations of the avant-garde network surpassed apparent cultural or linguistic boundaries. Each particular avant-garde group and periodical developed in a specific national, cultural and linguistic context, yet, due to the fact that all these formations received limited attention from their respective local environments, they sought a broader audience among other avant-garde groups from across the continent. The correspondence between Polish and Dutch artists reveals their shared interests in each other's works and viewpoints, and that their cooperation and mutual exchange was direct, i.e. without intermediaries from more pivotal nodes. As I have exemplified here, the avantgarde network was characterized by broad diffusion and rapid spreading of ideas and works, which in a broader perspective contributed to the development of modern literary, artistic and architectural thought in the interwar Europe, and beyond.

\section{Notes}

I For existing studies on Dutch-Polish relationships within the avant-garde network see e.g. S. Ex, 'De blik naar het oosten: De Stijl in Duitsland en OostEuropa', in De vervolgjaren van De Stijl I922-I932, ed. by C. Blotkamp (Amsterdam-Antwerpen: Uitgeverij L.J.Veen, I996), pp. 67-II2 and Theo van Doesburg en het Bauhaus: de invloed van De Stijl in Duitsland en Midden-Europa (Utrecht: Centraal Museum, 2000); J. Kleiverda, 'Henryk Stażewski. De Nieuwe Beelding in zijn werk en theorie', Jong Holland, 5, 2 (I989), 5-I7; K. Passuth, Les Avant-Gardes de l'Europe centrale: 1907-1927 (Paris: Flammarion, 1988) and 'De Stijl and the East-West Avant-garde: Magazines $\&$ the Formation of International Networks', in Van Doesburg \& the International Avant-Garde. Constructing a new world, ed. by G. Fabre and D. Wintgens Hötte (London: Tate Publishing, 2009), pp. 20-27; A. Turowski, 'De Stijl i polska awangarda', in P. Overy, De Stijl (Warszawa: Wydawnictwa Artystyczne i Filmowe, I979), pp. I40-I63; M. Wenderski, 'The influence of interpersonal relationships on the functioning of the constructivist network. A case 
study of Poland and the Low Countries', Journal of Dutch Literature, 6, 2 (2015), I-20. For a similar analysis of Polish-Belgian relationships see: M. Wenderski, 'Mutual exchange between Polish and Belgian modernist magazines as a case study in cultural mobility within the interwar network of the avant-garde', Tijdschrift voor Tijdschriftstudies, 37 (2015), 37-52.

2 M. I. Tuijn, Mon cher ami ... Lieber Does ... Theo van Doesburg en de praktijk van de internationale avant-garde (unpublished doctoral thesis, University of Amsterdam, 2003), pp. 2I-24.

3 Cf. Vantongerloo's letter to Seuphor from 3 November I950, Archief Michel Seuphor, Letterenhuis Antwerpen (LH), inv. No. I86967/II. Original spelling is kept in all the quotations and all the translations from Dutch, French and Polish are mine, M.W.

${ }_{4}$ Cf. H. L. C. Jaffé, De Stijl I917-I93I: The Dutch Contribution to Modern Art (Amsterdam: J. M. Meulenhoff, I956).

5 J. Martinet, The Next Call: avant-garde geschriften van Hendrik Werkman, uitgegeven van September 1923 tot November 1926 in Groningen (Utrecht: André Swertz, 1995), pp. 7-9.

6 Cf. Werkman's list of addresses to congenial journals and artists, Werkman Archief in Amsterdam (WA), inv. No. IIO.

7 M. Entrop and M. Verhoeff, 'Een vechttijdschrift, of de absolute nul: over Het Woord (1925-I926) van Jan Demets', De Parelduiker, 2, 5 (I997), 3-I9 (pp. 3-6). 8 "Duco Perkens," Het Woord, 2 (July I926), n. p.

9 A. Lehning, Internationale Revue iIo I927-I929 (Nendeln: Kraus Reprint, I979), p. 3.

Io A. H. den Boef and S. van Faassen, Van De Stijl en Het Overzicht tot De Driehoek (Antwerpen \& Apeldoorn: Garant, 2013), p. I36.

II Cf. G. C. Fabre, exhib. cat. Arte abstracto, arte concreto: Cercle et Carré, Paris, I930 (Valencia: IVAM Centre Julio Gonzalez, I990), p. I93.

I2 Cf. Vantongerloo's letter to Seuphor from 2I July I956, LH, inv. No. I86967/I5.

I 3 Cf. Seuphor's letter to van Doesburg from 8 January I930, Archive of Theo and Nelly van Doesburg, Rijksbureau voor Kunsthistorische Documentatie in The Hague (RKD), inv. No. I89 as well as Seuphor's letter to Werkman from I3 January I930, WA, inv. No. I.

I4 Cf. van Doesburg's letter to Seuphor from I 5 January I930, RKD, inv. No. I89.

I5 Cf. Torres-Garcia's letter to Seuphor (probably from 26 March 1930 - the letter is dated 'mercredi 26'), LH, inv. No. I86534/13.

I6 A. Kowalczykowa, Programy i spory literackie $w$ dwudziestoleciu I918-I939 (Warszawa: Ludowa Spółdzielnia Wydawnicza, I98I), pp. II3-I4.

I7 The last issue of the first volume (No. 6, I923) definitely distanced itself from the futurist movement, emphasized also in J. Przyboś, 'Idea rygoru', Zwrotnica, I2 (June I927), n. p.

I8 P. Strożek, 'Cracow and Warsaw: Becoming the Avant-Garde', in The Oxford Critical and Cultural History of Modernist Magazines. Volume III, Europe I880-I940, ed. by P. Brooker, et al. (Oxford: Oxford University Press, 20I3), pp. II84-207 (p. II97).

I9 Cf. Przybośs letter to Kurek from ro April I93I quoted in: T. Klak, Materialy do dziejów awangardy (Wrocław: Zakład Narodowy im. Ossolińskich, 1975), p. I05.

20 Cf. W. Kajruksztis and W. Strzemiński, exhib. cat. Katalog Wystawy Nowej Sztuki (Wilno: Lux, 1923).

2I Cf. A. Turowski, Malewicz w Warszawie: rekonstrukcje i symulacje (Kraków: Universitas, 2004). In I930 Malevich wrote to Strzemiński asking the $a$. $r$. group to organize his second exhibition in Warsaw. Moreover, according to Strzemiński, Malevich wanted to dissociate himself from Praesens due to its fascination with Le Corbusier - see Strzemiński's letter to Przyboś from 29 September 1930 quoted in: A. Turowski, 'Listy Władysława Strzemińskiego do Juliana Przybosia z lat 1929-I933', Rocznik Historii Sztuki, 9 (I973), 223-68 (p. 248).

22 A. Turowski, Konstruktywizm polski: próba rekonstrukcji nurtu (I92I-I934) (Wroclaw: Zaklad Narodowy im. Ossolińskich, I98I), pp. 74-78, 274.

23 Cf. Strzemiński's letters to Przyboś from 2I February to 9 June 1930 (Turowski 1973: 235-36, 242).

${ }_{24}$ Compare W. Strzemiński, 'Przedmiot i przestrzeń, Wiek XX, 2I (I928), 3; W. Strzemiński and S. Syrkus, 'Teraźniejszośc w architekturze i malarstwie', Przegląd Artystyczny, 4 (I928), 5-8 with W. Strzemiński, 'Snobizm a modernizm', Europa, 3 (I929), 88-90; 'Zasady nowej architektury', Linia, 3 (I93I), 68-69; 'Co myślę, o architekturze nowoczesnej', Wiadomości Literackie, 23 (I934), 4. as well as Strzemiński’s letters to Przyboś from I6 June, 27 June, I December I929, begin I 930 and 24 June I930 (Turowski I973: 223-25, 228-29, 23I-32, 242-44).

25 Cf. Brzękowski's letters to Przyboś from I3 May to 20 June 1930 quoted in: T. Klak, Źródta do histori awangardy (Wrocław: Zakład Narodowy im. Ossolińskich, I98I), pp. 62-66.

26 Z. Baranowicz, 'Grupa 'a. r.' w świetle korespondencji', Rocznik Historii Sztuki, 9 (1973), 295-96.

27 Archief van de werkgroep Mondriaan correspondentieproject, RKD, inv. nrs. 20, 23, 63, 75 . See also: L.A. Veen, Het geschreven werk van Piet Mondriaan (unpublished doctoral thesis, University of Utrecht, 20II), p. 220.

28 Cf. Brzękowski's letters to Przyboś from 2 June I929, I4 March and I3 May I930 (Klak I98I: 37-38, 59-60, 62-63) as well as Strzemiński’s letter to Przyboś from 8 September 1930 (Turowski I973: 247).

29 Cf. Brzękowski's letters to Kurek from I6 January, 27 April and 4 December I93I (Klak 
I975: 56-57, 62-63, 70-7I) and to Przyboś from 4 September I930 to I9 February I93I (Klak I98 I: $67-69,82-83$ ).

30 For Strzemiński's description of the history of Łódź Collection and Szczuka's opposition to the idea see his letter to Przyboś from 8 February I93I(Turowski I973: 252-53).

3I Cf. Seuphor's letter to Werkman from 25 August I924, WA, inv. No. I.

32 Cf. Berlewi's postcard to van Doesburg from I2 June I922, RKD, inv. No. 80 I.

33 A. Turowski, Budowniczowie świata: $z$ dziejów radykalnego modernizmu w sztuce polskiej (Kraków: Universitas, 2000), p. 383 .

34 The first page of Szczuka's manuscript is missing, cf. RKD, inv. No. 202.

35 S. Szczuka, 'Le mouvement artistique en Pologne', Anthologie du Groupe Moderne d'Art de Liège, 5, 3/4 (March/April I925), 4-5.

36 Cf. 'Alphabetische informatie: tijdschriften - boeken - artikelen enz.', De Stijl, 6, 8 (I924), Io9.

37 A. Baudin and P. M. Jedryka, L'Espace uniste: écrits $d u$ constructivisme polonais (Lausanne: L'Age d'Homme, 1977), p. 33; cf. K. Malevich, 'O sztuce', Blok, 2 (April I924), n. p.

38 Cf. 'Tijdschriften en boeken', De Stijl, 6, 8 (I924), II3-I6.

39 'Toegezonden tijdschriften en boeken', De Stijl, 7 , 75/76 (I926), 47-50.

40 Cf. De Stijl, 7, 79/84 (I927), 59-60, I I 4.

4I Cf. lists of subscribers to De Stijl, RKD, inv. No. 826.

42 'The Next Call onderhoudt internationaal verkeer met ...', The Next Call, 6 (October I924), n. p.

43 Cf. Syrkus's letter to Oud from I2 June I927, Archief J.J.P. Oud, Collectie Het Nieuwe Instituut in Rotterdam (NI), Copyright Pictoright, inv. No. 4I:27:I 54 .

44 S. Syrkus, 'L'architecture ouvrant le volume', Internationale Revue iIo, 5 (I927), I63-65.

45 Cf. Syrkus's letter to Oud from 29 September I929, NI, inv. No. 59:29:I3I.

46 T. van Doesburg, 'Kunst- en architectuurvernieuwing in Polen', Het Bouwbedrijf, 7, I8 (29 August 1930), 358-6I \& 8, 5 (27 February I93I), 87-90.

47 T. van Doesburg, 'Belangrijke nieuwe uitgaven over nieuwe architectuur', Het Bouwbedrijf, 7, 20 (26 September 1930), 40I-03.

48 Cf. Stażewski's, Nicz-Borowiakowa's and Strzemiński's letters to van Doesburg from resp. 3 November ( 2 letters) and 28 November I929, RKD, inv. Nos. 308; I42; I98.

49 Cf. van Doesburg's correspondence with Pronaszko, Minkiewicz, Sigalin and Stefanowicz, RKD, inv. Nos. I9I; 265; I60 \& I30 as well as SAP yearbook in van Doesburg's collection, RKD, inv. No. ARC/Does/doos LIV [982520].
50 Cf. van Doesburg's collection of photos, RKD, inv. Nos. I957; 2023; 2055; 2079; 2102; 2I20; 2I 53; 2156; $2159 \& 2160$

5 I S. Syrkus, 'Het nieuwe bouwen in Polen: de buitenmuur', de 8 en Opbouw, 6, I3 (23 June I934), I05-IO.

52 A. Boeken, 'Gli elementi dell'architettura funzionale Alberto Sartoris', de 8 en Opbouw, 3, I8 (2 September I932), I85.

53 K. L. Sijmons, 'Gang-woningen in het buitenland', de 8 en Opbouw, 7, I9 (I9 September 1936), 229.

54 'Buitenwanden in andere landen', de 8 en Opbouw, IO, I7/I8 (2 September I938), 205-08.

55 M. Stam, 'Mogelijke en onmogelijke krullen op de Expo I937', de 8 en Opbouw, I8, I8/I9 (I8 September I937), I7I.

56 G. Rietveld, 'Indrukken op de Parijsche tentoonstelling', de 8 en Opbouw, I8, I8/I9 (I8 September I937), I76. 57 Rietveld, pp. I80-I82.

58 I. Falkenberg-Liefrinck, 'Tijdschriften', de 8 en Opbouw, 6, 20 (28 September I935), 220.

59 'Rzeczy które mówią o nowym człowieku', Zwrotnica, 8 (June I926), 2II-I2.

60 Cf. Seuphor's letter to Brzękowski from 6 May I973, Muzeum Literatury im. A. Mickiewicza in Warsaw, inv. No. 2192, k. 53.

6I P. Mondrian, 'Nowa Plastyka', Europa, 3 (November I929), 90-9I; T. van Doesburg, 'Uwagi. Ankieta Europy', Europa, 2 (October I929), 60-6I; 'Deklaracja sztuki konkretnej', Europa, II (August I930), 34I.

62 Cf. Brzękowski’s letter to Przyboś from 26 January I932 (Kłak I98 I: 95-96).

63 Van Doesburg and van Eesteren were the co-authors of both works reproduced in the fifth issue of Blok, although the descriptions in the journal state otherwise.

64 T. Van Doesburg, 'Odnowienie architektury', Blok, 5 (July I924), I2-I3. Cf. T. Van Doesburg, 'Tot een beeldende architectuur', De Stijl, 6, 6/7 (I924), 78-83.

65 Red. [= M. Szczuka and T. Żarnower], 'Co to jest konstruktywizm', Blok, 6/7 (September I924), n.p.

66 Turowski, Budowniczowie ..., p. 40.

67 Cf. Syrkus's and Rutkowski's letters to Oud from resp. 5 October and December 1925, NI, inv. Nos. 26:25:2I \& 25:26:269.

68 Van Doesburg mentions it in his letter to the editors of Praesens from 1926, RKD, inv. No. 308.

69 Cf. Rutkowski's letter to Oud from 20 January I926, NI, inv. No. 28:26:I4.

70 P. Meller, 'Nowoczesna architektura holenderska', Blok, II (March I926), n.p.

7I Cf. Praesens's letter to van Doesburg from 23 January I926, RKD, inv. No. 308.

72 Cf. van Doesburg's letter to Praesens from early 1926 (reaction on the letter from 23 January 1926) and Praesens's letter to van Doesburg from 20 March I926, RKD, inv. No. 308 . 
73 Cf. Syrkus's letter to Oud from I April I926, NI, inv. No. 29:26:35. Notably, in the same letter Syrkus also shared very positive reactions to Oud's works exhibited in Warsaw.

74 Cf. Oud's letter to Syrkus from I2 April I926, NI, inv. No. 29:26:46.

75 Cf. Syrkus's letter to Oud from I6 June I926, NI, inv. No. 31:26:108.

76 Cf. van Doesburg's correspondence with Praesens, RKD, inv. Nos. 201 \& 308.

77 Cf. van Doesburg's letter to the editors of Praesens from I926, RKD, inv. No. 308.

78 Cf. Syrkus's letter to van Doesburg from I 3 November I926, RKD, inv. No. 20 I.

79 Cf. Syrkus's letter to Oud from I4 December I929, NI, inv. No. 60:29:15I.

80 Cf. Syrkus's letters to Oud from I6 June I926, I2 June I927 and 29 September 1929, NI, inv. Nos. 31:26:108; 4I:27:I 54 \& 59:29:I3I.

8I Cf. Syrkus's letters to Oud from I2 June 1927 and 29 September I929, NI, inv. Nos. 4I:27:I54 \& 59:29:I3I.

82 'Książki nadesłane I927-I930', Praesens, 2 (May I930), I9I-97.

83 'Czasopisma zagraniczne', Praesens, 2 (May I930), I98.

\section{Funding}

This work was supported by National Science Centre, Poland [grant number $20 \mathrm{I}_{4} / \mathrm{I}_{3} / \mathrm{N} /$ $\mathrm{HS}_{2} / \mathrm{O}_{2757}$ ] and Adam Mickiewicz University Foundation in Poznań [scholarship for 20I5/20I6]

\section{Notes on contributor}

Michał Wenderski (M.A.Sc.) is an architect, translator and scholar of modern Dutch literature. Currently a Ph.D. candidate at Adam Mickiewicz University in Poznań, Poland, and the head of a research project in the field of cultural mobility between Poland and the Low Countries in the I920s (National Science Centre, Poland; 20I4/I3/N/HS2/02757). Author of several publications on the interwar aesthetic avant-garde in the fields of literature, fine arts and architecture; holder of a scholarship from the Adam Mickiewicz University Foundation in Poznań for 2015/2016.

Correspondence to: Michał Wenderski, Adam Mickiewicz University in Poznań, Poland.Email: mwenderski@wa.amu.edu.pl
84 T. van Doesburg, 'Ewolucja architektury nowoczesnej w Holandji', Architektura i Budownictwo (AiB), 8/9 (I93I), 338-40.

5 J. J. P. Oud, 'Wplyw Frank Lloyd Wright'a na 86 P. M. Lubiński, 'Współczesna architektura holenderska', $A i B, \mathrm{I} / 2$ (1930), 57-66; $A i B, 3$ (1930), 99-II3; $A i B, 4 / 5$ (I930), I93-200; $A i B, 6$ (I930), 22839; $A i B, 7$ (I930), 259-72.

87 A. Lauterbach, 'Tanie mieszkania w Holandji', $A i B$, 4 (I925/I926), 3I-33; Anonym, 'Technika budowy serjami domów w Holandji', $A i B$, I (I928), 27; Anonym, 'Organizacje Architektoniczne w Holandji', $A i B, 6$ (1934), 200; P. M. Lubiński, 'H. P. Berlage', AiB, I934), 360-6I

w Warszawie', Architekt, 2I, 5 (I926), I-I7.

89 H. Kunzek, 'Kilka uwag o Wystawie Sztuki Dekoracyjnej w Paryżu', Architekt, 20, 5 (I925), I-24. J. Struszkiewicz, 'Ze świata', Architekt, 22, 5 (I929), I6.

Vantongerloo corresponded with Polish artists on this issue, cf. Archiwum IPS, Institute of Art, Polish Academy of Science in Warsaw, inv. No. 70. 